\title{
The Role of Saving and Credit Cooperatives in Improving Rural Micro Financing: The Case of Bench Maji, Kaffa, Shaka Zones
}

\author{
Mr. Tesfaye Megiso Begajo \\ Department of Cooperatives, College of Business and Economics, Mizan-Tepi University \\ PO Box 260, Mizan Teferi, Ethiopia
}

Tel: 251-946-511-347Ｅ-mail: yenegetarobel604@ gmail.com

Received: November 2, 2018 Accepted: December 6, 2018 Published: December 10, 2018

doi:10.5296/wjbm.v4i2.13849 URL: https://doi.org/10.5296/wjbm.v4i2.13849

\begin{abstract}
Microfinance is the provision of microloans to poor entrepreneurs and small businesses lacking access to banking and related services. Saving and Credit Cooperative are the main source of finance for people who have low income level. In this study the role of saving and credit cooperatives in improving rural micro financing in Bench Maji, Kaffa, and Shaka Zones was examined. Methodologically descriptive survey research was applied. Ideological preparedness of community on saving, tool to improve members saving culture, members' actual deposit, and loan facilities performed by cooperatives were the focuses in this study. The findings show that there is a contribution in changing the saving culture of the members, monthly deposit, and loan disbursement capacity. The challenges are shortage of finance for loan, irregularity in saving, weak collection of loan receivables, no collaboration with other financial institutions, limitation in awareness creation, and limited support of government to lower administrative level. Therefore, to fulfil the members' financial need cooperatives have to increase the number of members, the Government should establish strong education, training, and information unit at Zone and Woreda level, without abiding cooperative rules should arrange capital injection and collaboration with Micro financial Institutions, private and public banks.
\end{abstract}

Keywords: Saving culture, Saving, Credit, Microfinance, Cooperative principle 


\section{Introduction}

\subsection{Background}

Microfinance is the provision of financial services including savings, transfers, insurance and credit for the poor (Pacific Financial Inclusion Program, 2009). Today there is broad awareness that poor people have many and diverse financial service needs, which are typically met by a variety of providers through multiple financial services (The World Bank, 2013 , p. 1). Microfinance, according to Otero (1999, p. 8) is "the provision of financial services to low-income poor and very poor self-employed people" (Wrenn, 2005). Collective and cooperative support is a critical microfinance strategy at both the local level, in the form of the solidarity groups, and at the national and regional level in the form of networking groups. Cooperatives as an economic enterprise and self-help organizations play a meaningful role in uplifting the socio-economic conditions of their members and their local communities. The Government of Ethiopia has identified the cooperative form of organizations as instrument to socio-economic development, hence supported cooperatives for decades to improve agricultural production and productivity. Ethiopians have a strong tradition of saving, which is evident from the widespread existence of informal rotating savings and credit organizations such as iqubs and iddirs.

In Ethiopia, the history of modern cooperatives was started in 1960 (FCA, 2012). Establishment of saving and credit cooperative societies in Ethiopia started in the mid-1960s (Muluneh, 2012). There is also a promising history in the country of successful savings and credit cooperatives in urban areas (FCA, 2012). Federal cooperative Agency (FCA) of Ethiopia also reported that for the last five years growth and transformation plan (GTP I, 2011-2015), saving and credit cooperative were planned to mobilize 2.5 billion birr saving and mobilized 5.5 million birr by members. The history of cooperative movements in Ethiopia has demonstrated the potential for growth and expanded outreach in the success of nearly 700 mainly urban based saving and credit cooperatives. There is a sound legal and policy framework conducive to the establishment of financially and politically independent rural and urban saving and credit cooperatives (Wolday, 2004). Karagu and Okibo (2014) SACCOs play a significant role in the provision of financial services to the poor (target groups).

\subsection{Statement of the Problem}

Society's access to financial services depends on many variables such as financial development of the country, income level of the individuals, geographic location and development of the country accompanied by other variables. That means even though financial service is vital to the society, it is not equally available to all members of society. Hence, Savings and Credit Cooperatives (SACCOs) are established based on this premise to serve the interest of economically neglected segment of society. SACCOs are the main providers of financial services for low income, rural and urban societies who are overlooked by formal financial institutions in many countries (Nigusie, 2015).

Saving and credit cooperatives have been playing a distinct and important role in providing 
various financial services in rural areas of Ethiopia. However, the performance of rural financial cooperatives in mobilization of saving and provision of credit has been inadequate (Kifle \& Hailemichael, 2013). The most critical challenges facing Mwalimu (Kenya) SACCO Co-operatives are among others, lack of standardized accounting and prudential standards, lack of concessionary credit facilities previously given by Government with donor contributions (Olga, Gladys, \& Anyango, 2017). SACCOs invested much of their financial resources in less productive/profitable assets, financed their assets using much capital from members' share capital which cannot be used for loan disbursement, instead of saving deposits. The capacity of the RUSACCOs to generate adequate amount of profit was also found substantially below the standard (Aregawi, 2014). It seems that few attempts have been made to assess the role of saving and credit cooperatives in improving the rural micro financing. Therefore, as to the knowledge of the researcher, it is worth mentioning that a closer assessment of the role of saving and credit cooperatives in improving the rural micro financing is made in Bench Maji, Kaffa and Shaka zones.

\subsection{Objectives of the Study}

The General objective of this study was to assess the role of saving and credit cooperatives in improving the rural micro financing. Specifically to:-

Identify the contribution of SACCOs in changing the saving culture of the members.

Evaluate the loan facilitation performance of the SACCOs in the study area.

Evaluate the financial flow in rural micro-financing based on SACCO's effort.

Identify the challenges and opportunities of SACCOs to their business activities in the study area.

\section{Review of Related Literature}

\subsection{Concept of Microfinance}

Schreiner and Colombet (2001, p. 339) define microfinance as "the attempt to improve access to small deposits and small loans for poor households neglected by banks." Therefore, microfinance involves the provision of financial services such as savings, loans and insurance to poor people living in both urban and rural settings who are unable to obtain such services from the formal financial sector. When properly harnessed, microfinance offers a variety of benefits to the African people. Foremost, microfinance initiatives can effectively address material poverty, the physical deprivation of goods, services, and the income to attain them (Microfinanceinafrica.pdf, accessed, 2018). Srinivasan and Sriram (2003) More important than the hedge fund or the liquid-yield option note was the finding that the poor can save, can borrow (can indeed decide on loans to fellow poor), and will certainly repay loans.

\subsection{Concepts of Cooperatives}

The idea of Cooperation is older than man himself. Human being is a social animal who needs support from each other in order to make nature suitable for his existence. Ancient people engaged in a collective manner to gather their food and to protect themselves from 
harmful wild animals. As we learnt from history, today's civilization is the result of collective effort of people conducted to win social and economic problems. Traditional cooperation was the spring board for the emergence of modern cooperatives. But cooperation as a form of economic organization is of recent origin

Modern cooperatives have started during the industrial revolution, early 19th century. This period was a period of considerable stress and difficulties in England. Great changes took place in the economic system, the introduction of the steam engine and the mechanization processes revolutionized the industry. This was the time when the society divided in to capitalist and wage earning workers. The blind capitalist economic system started to exploit the life of workers. At that time social thinkers like Robert Owen (1771-1858) tried to create a better economic system that stops exploitation of man by man. After great effort of Robert Owen and his followers the first modern consumers' cooperative was established in 1844 in England (Rochidale). This was the time when modern cooperative ideology put in to practice (FCA, 2007).

\subsection{Definition of SACCOS}

Kimberly, Zeuli, and Robert (1980) United States Department of Agriculture (USDA) in 1987 defined as "A Cooperative is a user-owned, user-controlled business that distributes benefits in the basis of use." SACCOs are user-owned financial institutions that offer both savings and credit services to their members. Getachew (2006) in SACCO Society once overhead and other expenses are paid, reserve for cushion against any loss, and for expansion of services set aside, the remaining income from loans is returned back to members in the form of dividend on savings, share or both. The difference between a SACCO and other forms of co-operatives is that the SACCO can accept deposits from its members as savings and also issue out loans to qualifying members of the SACCO (Henama, 2012).

\subsubsection{Types of SACCOs}

According to Bwana and Mwakujonga (2013), various types of SACCOs exist depending on the membership profile and the products extended to the members differ accordingly. In essence, there are three broad categories of SACCOs such as community-based SACCOs, employee-based SACCOs, and agricultural SACCOs. Most of the Non-English speaking nations in Africa started appreciating SACCOs in 1960s, with major influx into SACCO community in 1970s (Mwakajumilo, 2011), Alila and Obado (1990), Olando, Mbewa, and Jagongo (2012), and Muluneh (2012).

\subsection{Empirical Review}

In case of the role of SACCO; access to finance offered by SACCOs influences growth of youth entrepreneurship (Mwangi \& Wanjau, 2013), SACCOS have enabled members to put some of their loans in agricultural development thereby increasing the productivity in the agricultural sector and enhancing food security (Okoye, 2009), and the participation of males and females in getting access to loans within the SACCOs was high. The SACCOs also provide loans to all members without gender discrimination (Dessalew, 2014). Saving and Credit Cooperatives are formed with sole purpose of improving member's welfare through 


\section{Macrothink}

returns on savings and loans facilities among other products (Osoti, 2014), there is a significant positive relationship between the financing strategies and the outreach of SACCOs (Mohammed, 2011), Kifle (2011 \& 2012) there is a substantial growth in outreach and improvement of operational Self-Sufficiency.

\section{Research Methodology}

\subsection{Description of the Study Area}

The study area consists of three zones including Bench-Maji, Kaffa, and Sheka Zones which are one of 13 zones and one city administration found SNNPRS.

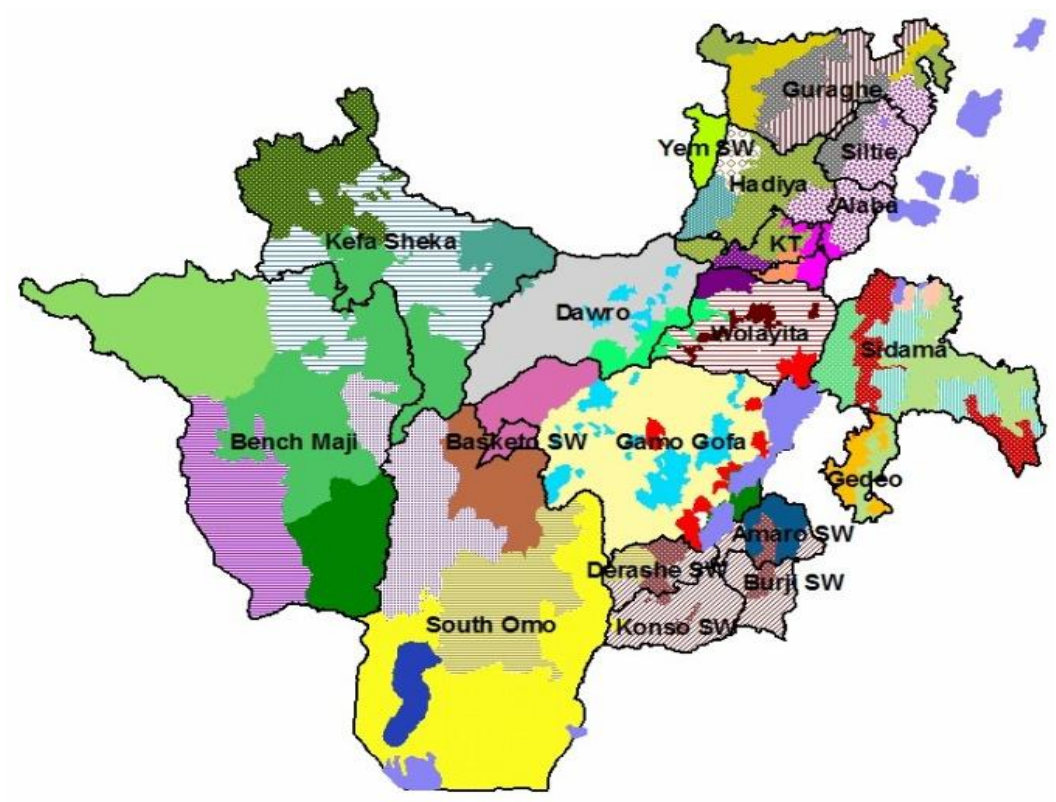

Figure 1. Map of the study areas

Source: https://Southern_Nations,_Nationalities,_and_Peoples\%27_Region.

\subsection{Research Design}

The research was done through descriptive type of research emphasizing both quantitative and qualitative data. A cross sectional survey of collecting five years (2011-2015) data in financial performance was undertaken. Both primary and secondary data were collected. The sources of primary data were members, cooperative BODs, managers, and employees, zones and Woreda cooperative officers, related government official. Secondary data was gathered from SACCOs and zonal promotion office annual performance and financial reports, bylaws, credit documents.

Regarding sample size determination and sampling techniques all three zones and 4 cooperative unions were taken as they are, out of 27 woreda's found in three zones only 12 woreda's were selected based on the existence of active primary saving and credit cooperatives. In third stage the selection of primary saving and credit cooperatives was employed based on the activity in those cooperatives at current time and those cooperatives 


\section{Macrothink}

World Journal of Business and Management

ISSN 2377-4622

2018, Vol. 4, No. 2

having age of five year and above. Hence, 32 primary saving and credit cooperatives were considered for sample out of 132 primary saving and credit cooperatives. Finally at fourth stage to select the sample respondent members' (Carvalho, 1984) had been used. Additionally for key informants' interview 4 managers, 4 accountants of the unions, and 3 cooperative office heads from three zones were purposefully selected.

Table 1. Carvalho sample size determination method

\begin{tabular}{|l|c|c|c|}
\hline Population & \multicolumn{3}{|c|}{ Sample size } \\
\hline $51-90$ & Low & Medium & Large \\
\hline $91-150$ & 5 & 13 & 20 \\
\hline $151-280$ & 8 & 20 & 32 \\
\hline $281-500$ & 13 & 32 & 50 \\
\hline $501-1200$ & 20 & 50 & 80 \\
\hline $1201-3200$ & 32 & 80 & 125 \\
\hline $3201-10000$ & 50 & 125 & 200 \\
\hline $10001-35000$ & 80 & 200 & 315 \\
\hline $35000-150000$ & 125 & 315 & 500 \\
\hline
\end{tabular}

The total members of the cooperatives are 15,371 which is found in the range of 10,001-35,000. Therefore, the third one or large sample /315/ was considered as a sample. Additionally 84 cooperative office employees and administrative counsels were selected.

Table 2. Sample size

\begin{tabular}{|c|c|c|c|c|c|c|}
\hline Zone & Woreda & $\begin{array}{c}\text { No of Primary } \\
\text { Coop. }\end{array}$ & $\begin{array}{c}\text { Samples } \\
\text { members from e }\end{array}$ & Total & $\begin{array}{l}\text { Woreda } \\
\text { Experts }\end{array}$ & G/Total \\
\hline \multirow{4}{*}{$\begin{array}{l}: \bar{J} \\
\sum^{\pi} \\
\bar{D} \\
\bar{D} \\
\infty\end{array}$} & Magi & 3 & 10 & 30 & 7 & 37 \\
\hline & Debu Bench & 2 & 10 & 20 & 7 & 27 \\
\hline & Gura Ferda & 2 & 10 & 20 & 7 & 27 \\
\hline & Semen Bench & 2 & 10 & 20 & 7 & 27 \\
\hline \multirow{5}{*}{$\underset{\mathscr{\pi}}{\mathscr{\pi}}$} & Ginbo & 3 & 10 & 30 & 7 & 37 \\
\hline & Bonga & 3 & 10 & 30 & 7 & 37 \\
\hline & Gewata & 3 & 10 & 30 & 7 & 37 \\
\hline & Bita & 2 & 10 & 20 & 7 & 27 \\
\hline & Gesha & 4 & 10 & 40 & 7 & 47 \\
\hline \multirow{3}{*}{$\begin{array}{l}\frac{\pi}{0} \\
\frac{\pi}{\pi}\end{array}$} & Yeki & 3 & 10 & 30 & 7 & 37 \\
\hline & Masha & 3 & 10 & 30 & 7 & 37 \\
\hline & Andracha & 2 & 10 & 20 & 7 & 27 \\
\hline Total & 12 & 32 & 120 & 320 & 84 & $\underline{\underline{404}}$ \\
\hline
\end{tabular}




\section{Macrothink}

World Journal of Business and Management

ISSN 2377-4622

2018, Vol. 4, No. 2

Following the completion of the data collection, the data was edited, coded and entered into the Statistical Package for Social Science (SPSS version 20) computer program for the purpose of tabulation, frequency and percentage analysis. The data was analyzed using descriptive statistical tools such as percentage and frequency, and presented in table. The qualitative data were analyzed through discussion by evaluating the content from the response of open-ended questionnaire.

\section{Results and Discussion}

\subsection{Results}

\subsubsection{Demographic Characteristics of Respondents}

In this study, 320 individuals who were active members and 84 woreda promotion officers of the cooperative society were participated in the study. Fortunately, all selected samples participated in the study and the overall response rate was $100 \%$. In order to have basic information about these respondents, data on socio-demographic characteristics like sex, age, education level, marital status, family size, and membership situation of the members have been collected. Based on the cooperative meaning the investigator interested on identifying whether the membership participation in cooperatives is balanced in between different parties in the community.

Table 3. Demographic characteristics (sex and age) of respondents

\begin{tabular}{|c|c|c|c|}
\hline Description & Category & Frequency & Percent \\
\hline Sex Distribution & Male & 240 & 75.0 \\
\cline { 2 - 4 } & Female & 80 & 25.0 \\
\cline { 2 - 4 } & Total & $\mathbf{3 2 0}$ & $\mathbf{1 0 0 . 0}$ \\
\hline Age Distribution & Below 20 years & 7 & 2.2 \\
\cline { 2 - 4 } & 21-30 years & 114 & 35.6 \\
\cline { 2 - 4 } & 31-40 years & 111 & 34.7 \\
\cline { 2 - 4 } & 41-50 years & 63 & 19.7 \\
\cline { 2 - 4 } & 51-60 years & 20 & 6.3 \\
\cline { 2 - 4 } & Above 60 years & 5 & 1.6 \\
\cline { 2 - 4 } & Total & $\mathbf{3 2 0}$ & $\mathbf{1 0 0 . 0}$ \\
\hline
\end{tabular}

Source: Own survey, 2017.

The table above shows that out of 320 member respondents $240(75 \%)$ are males and the rest $80(25 \%)$ are female. On this concern the above table display as $7(2.2 \%)$ of the total respondents are below 20 years, 114(35.6\%) are in between 21-30 years, 111(34.7\%) are in between 31-40 years, 63(19.7\%) are in between $41-50$ years, 20(6.3\%) are 51-60 years, and the rest $5(1.6 \%)$ are above 60 years. Therefore, most of the participants or members in SACCO at the study area are at the age of 21-40 years. 
Table 4. Demographic characteristics (education \& marital status) of respondents

\begin{tabular}{|l|l|c|c|}
\hline \multicolumn{1}{|c|}{ Description } & \multicolumn{1}{|c|}{ Category } & Frequency & Percent \\
\hline Education Level of Respondents & Illiterate & 51 & 15.9 \\
\cline { 2 - 4 } & From grade 1-8 & 154 & 48.1 \\
\cline { 2 - 4 } & Grade 9-12 & 43 & 13.4 \\
\cline { 2 - 4 } & Certificate & 7 & 2.2 \\
\cline { 2 - 4 } & Diploma & 31 & 9.7 \\
\cline { 2 - 4 } & Degree and above & 34 & 10.6 \\
\cline { 2 - 4 } & Total & $\mathbf{3 2 0}$ & $\mathbf{1 0 0 . 0}$ \\
\hline Marital status of Respondents & Single & 69 & 21.6 \\
\cline { 2 - 4 } & Married & 7 & 75.3 \\
\cline { 2 - 4 } & Divorced & 3 & 2.2 \\
\cline { 2 - 4 } & Widowed & $\mathbf{3 2 0}$ & $\mathbf{1 0 0 . 0}$ \\
\cline { 2 - 4 } & Total & & \\
\hline
\end{tabular}

Source: Own survey, 2017.

Based on the data collected 51(15.9\%) are illiterate, 154(48.15\%) are $1-8^{\text {th }}$ grade, $43(13.4 \%)$ are $9-12^{\text {th }}$ grade, $7(2.2 \%)$ are Certificate holders, 31(9.7\%) are Diploma holders, and the rest $34(10.6 \%)$ have first Degree. Since the study was focused on rural SACCO the literacy composition is good to manage the Cooperative society. Collecting data on marital status for this study is required because the financial need among single and married individuals may vary based on their consumption requirement. Table 4 above indicates that out of 320 respondents $69(21.6 \%)$ are single, 241(75.3\%) are married, $7(2.2 \%)$ are divorced, and 3(0.9\%) are widowed.

Table 5. Demographic characteristics (family \& membership) of respondents

\begin{tabular}{|l|l|c|c|}
\hline \multicolumn{1}{|c|}{ Description } & Category & Frequency & Percent \\
\hline Family size of respondents & Below 5 & 137 & 42.8 \\
\cline { 2 - 4 } & $5-8$ & 157 & 49.1 \\
\cline { 2 - 4 } & $9-10$ & 20 & 6.3 \\
\cline { 2 - 4 } & Above 10 & 6 & 1.9 \\
\cline { 2 - 4 } & Total & $\mathbf{3 2 0}$ & $\mathbf{1 0 0 . 0}$ \\
\hline Duration of Membership & Less than 6 month & 16 & 5 \\
\cline { 2 - 4 } & 6 month -2 years & 61 & 19 \\
\cline { 2 - 4 } & Above 2 years & 243 & 76 \\
\cline { 2 - 4 } & Total & $\mathbf{3 2 0}$ & $\mathbf{1 0 0}$ \\
\hline
\end{tabular}

Source: Own survey, 2017.

Regarding the family size from 320 respondents 137 (42.8\%) have below 5 family members, $157(49.1 \%)$ consists 5-8 family members, 20 (6.3\%) has 9-10 family members, and $6(1.9 \%)$ 
has more than 10 family members. According to the above table $6(5 \%)$ has below 6 month in membership, 61 (19\%) has 6 month up to 2 years, and $243(76 \%)$ has two years and above membership age.

\subsubsection{Contribution of SACCO's in Changing the Saving Culture of the Members}

In Ethiopia the saving culture of the community in general has limitation. To change this trend many saving and credit cooperatives have been established with the objective of changing the saving culture of the community. Therefore, to know the contribution of saving and credit cooperatives in changing the saving culture of members the researcher used two factors like training and the regular deposit of saving by the members in the cooperative society.

Table 6. Change in saving culture of members

\begin{tabular}{|l|c|c|c|}
\hline \multicolumn{1}{|c|}{ Description } & Response & Frequency & Percent \\
\hline Does the Saving Culture of Members & Yes & 309 & 96.6 \\
\cline { 2 - 4 } Changed due to Membership? & No & 11 & 3.4 \\
\cline { 2 - 4 } & Total & $\mathbf{3 2 0}$ & $\mathbf{1 0 0}$ \\
\hline
\end{tabular}

Source: Own Survey, 2017.

The table 4 above shows that out of the total respondents 309 (96.6\%) replied that their saving culture is changed after they have been a member of saving and credit cooperative society. Whereas only $11(3.4 \%)$ respondents said that there is no change in their saving culture.

Table 7. Training on improving members saving culture

\begin{tabular}{|l|l|c|c|c|c|}
\hline \multirow{2}{*}{ Description } & \multicolumn{2}{|c|}{ Response } & \multicolumn{4}{c|}{ Item } \\
\cline { 3 - 6 } & & None & Once & Twice & Total \\
\hline \multirow{2}{*}{$\begin{array}{l}\text { Frequency of Members Training } \\
\text { from the SACCO }\end{array}$} & Frequency & 145 & 134 & 41 & 320 \\
\cline { 2 - 6 } & Percent & 45.3 & 41.9 & 12.8 & 100.0 \\
\hline \multirow{2}{*}{$\begin{array}{l}\text { Does the training improved members } \\
\text { saving Culture? }\end{array}$} & Response & \multicolumn{2}{|c|}{ Yes } & No & Total \\
\cline { 2 - 6 } & Frequency & \multicolumn{2}{|c|}{102} & 73 & 175 \\
\cline { 2 - 6 } & Percent & \multicolumn{2}{|c|}{58.28} & 41.72 & 100.0 \\
\hline
\end{tabular}

Source: Own Survey, 2017.

Regarding the training frequency out of 320 respondents 145 (45.3\%) replied that they didn't trained at all, $134(41.9 \%)$ got training once and the rest $41(12.8 \%)$ trained twice. Improvement of the saving culture due to training indicated as more than half $(58.28 \%)$ of the members believed that the training improved their saving culture, where as $41.72 \%$ said no. 


\section{MInstitute Macrothink $^{\text {Int }}$}

Table 8: The amount of annual deposit of members in Birr

\begin{tabular}{|l|c|c|c|c|c|c|c|c|c|c|c|c|c|}
\hline \multirow{3}{*}{ Zone } & \multicolumn{9}{|c|}{ Compulsory Saving (CS) } & \multicolumn{5}{c|}{ *Vluntary Saving (VS) } & \multirow{2}{*}{ G/ Total } \\
\cline { 2 - 14 } & $\mathbf{2 0 1 1}$ & $\mathbf{2 0 1 2}$ & $\mathbf{2 0 1 3}$ & $\mathbf{2 0 1 4}$ & $\mathbf{2 0 1 5}$ & Total & $\mathbf{2 0 1 1}$ & $\mathbf{2 0 1 2}$ & $\mathbf{2 0 1 3}$ & $\mathbf{2 0 1 4}$ & $\mathbf{2 0 1 5}$ & Total & \\
\hline B/Maji & 2720 & 6240 & 6580 & 7,000 & 7200 & 29,740 & 0 & 6685 & 22000 & 11272 & 32,656 & 72,613 & $\mathbf{1 0 2 , 3 5 3}$ \\
\hline Keffa & 9600 & 10320 & 10280 & 12000 & 11,942 & 54,142 & 6011 & 1500 & 17000 & 24356 & 30,772 & 79,639 & $\mathbf{1 3 3 , 7 8 1}$ \\
\hline Sheka & 5200 & 5600 & 6400 & 6325 & 6,400 & 29,925 & 0 & 670 & 19245 & 7675 & 14,444 & 42,034 & $\mathbf{7 1 , 9 5 9}$ \\
\hline Total & $\mathbf{1 7 , 5 2 0}$ & $\mathbf{2 2 , 1 6 0}$ & $\mathbf{2 3 , 2 6 0}$ & $\mathbf{2 5 , 3 2 5}$ & $\mathbf{2 5 , 5 4 2}$ & $\mathbf{1 1 3 , 8 0 7}$ & $\mathbf{6 , 0 1 1}$ & $\mathbf{8 , 8 5 5}$ & $\mathbf{5 8 , 2 4 5}$ & $\mathbf{4 3 , 3 0 3}$ & $\mathbf{7 7 , 8 7 2}$ & 194,286 & $\mathbf{3 0 8 , 0 9 3}$ \\
\hline
\end{tabular}

Source: Basic Data from Zone Cooperative Offices, 2017.

The table above indicates that the annual deposit of members shows that there is a change in the saving culture of community as well as organized cash flow towards rural area. The above information is only shows about samples, where taken as the representative of population. If the average compulsory saving is multiplied to the population $(15,361$ members) the annual deposit will be 5,463,091.65 birr. Saving and credit Cooperatives provide voluntary saving service both to the members and non-members in order to mobilized saving. Though there is irregularity the data above shows us there is about 194,286 birr annual voluntary saving in study area.

Table 9. Annual growth rate of compulsory saving (in Percent)

\begin{tabular}{|l|c|c|c|c|c|c|c|c|c|c|c|}
\hline Zone & No. of & \multicolumn{10}{|c|}{ Compulsory Saving (CS) } \\
\cline { 3 - 12 } & Savers & $\begin{array}{c}\mathbf{2 0 1 1} \\
(\mathbf{a})\end{array}$ & $\begin{array}{c}\mathbf{2 0 1 2} \\
(\mathbf{b})\end{array}$ & $\begin{array}{c}\text { Rate(a/b) } \\
\mathbf{\%}\end{array}$ & $\begin{array}{c}\mathbf{2 0 1 3} \\
\mathbf{C}\end{array}$ & $\begin{array}{c}\mathbf{b} / \mathbf{c} \\
(\boldsymbol{\%})\end{array}$ & $\begin{array}{c}\mathbf{2 0 1 4} \\
(\mathbf{d})\end{array}$ & $\begin{array}{c}\mathbf{c} / \mathbf{d} \\
(\boldsymbol{\%})\end{array}$ & $\begin{array}{c}\mathbf{2 0 1 5} \\
(\boldsymbol{\epsilon})\end{array}$ & e/d & $\begin{array}{c}\text { Average } \\
\text { Growth (\%) }\end{array}$ \\
\hline $\begin{array}{l}\text { Bench } \\
\text { Maji }\end{array}$ & 90 & 2720 & 6240 & 56.4 & 6580 & 5.2 & 7,000 & 6.0 & 7200 & 2.8 & 17.6 \\
\hline Keffa & 150 & 9600 & 10320 & 7.0 & 10280 & -0.4 & 12000 & 14.3 & 11,942 & -0.5 & 5.1 \\
\hline Sheka & 80 & 5200 & 5600 & 7.1 & 6400 & 12.5 & 6325 & -1.2 & 6,400 & 1.2 & 4.9 \\
\hline Total & $\mathbf{3 2 0}$ & $\mathbf{1 7 5 2 0}$ & $\mathbf{2 2 1 6 0}$ & $\mathbf{2 0 . 9}$ & $\mathbf{2 3 2 6 0}$ & $\mathbf{4 . 7}$ & $\mathbf{2 5 , 3 2 5}$ & $\mathbf{8 . 2}$ & $\mathbf{2 5 5 4 2}$ & $\mathbf{0 . 8}$ & $\mathbf{8 . 6 5}$ \\
\hline
\end{tabular}

Source: Basic Data from Zone Cooperative Offices, 2017.

In above table there is an increase in annual deposit of members except 2013G.C and 2015 G.C in Kaffa and 2014 G.C in Sheka Zone saving and credit cooperatives. On average there is positive growth rate $(8.65 \%)$ of members saving in the study areas.

\subsubsection{The Loan Facilitation Performance of Saving and Credit Cooperatives}

The concept of loan facilitation in this section includes availing enough finance for loan disbursement service, determining reasonable interest rate, and provision of loan focused laws with clear setting of criteria how to lend the loan to the members and repayment period. 
Table 10. Source of loan before joining SACCO

\begin{tabular}{|l|l|c|c|}
\hline Description & Category & Frequency & Percent \\
\hline \multirow{3}{*}{$\begin{array}{l}\text { Source of loan before } \\
\text { joining SACCO }\end{array}$} & Friends/Family & 184 & 57.5 \\
\cline { 2 - 4 } & Local Money Lender & 67 & 20.9 \\
\cline { 2 - 4 } & OMF & 12 & 3.8 \\
\cline { 2 - 4 } & Other Cooperatives & 4 & 1.3 \\
\cline { 2 - 4 } & Other & 53 & 16.6 \\
\cline { 2 - 4 } & Total & $\mathbf{3 2 0}$ & $\mathbf{1 0 0 . 0}$ \\
\hline
\end{tabular}

Source: Own Survey, 2017.

As displayed above more than half of the respondents $184(57.5 \%)$ got loan from their friends/families, 67(20.9\%) from local money lenders, 12(3.8\%) from Omo Micro Finance, $4(1.3 \%)$ from other cooperatives, and $53(16.6 \%)$ get loan from other sources.

Table 11. Borrowing frequency

\begin{tabular}{|c|l|c|c|}
\hline \multicolumn{1}{|c|}{ Description } & Category & Frequency & Percent \\
\hline Borrowing Frequency of the & None & 72 & 22.5 \\
\cline { 2 - 4 } Members from their SACCO & Once & 56 & 17.5 \\
\cline { 2 - 4 } & Twice & 70 & 21.9 \\
\cline { 2 - 4 } & Three Time & 94 & 29.4 \\
\cline { 2 - 4 } & Above Three Time & 28 & 8.8 \\
\cline { 2 - 4 } & Total & $\mathbf{3 2 0}$ & $\mathbf{1 0 0 . 0}$ \\
\hline
\end{tabular}

Source: Own Survey, 2017.

In the table above as out of 320 respondents $72(22.5 \%)$ are not borrowed at all, $56(17.5 \%)$ borrowed at once, $70(21.9 \%)$ borrowed twice, 94 (29.4\%) borrowed three times, and the remaining $28(8.8 \%)$ are borrowed above three times. In total $77.5 \%$ were got loan from their SACCO.

Table 12. Purpose of loan

\begin{tabular}{|l|l|c|c|}
\hline Description & \multicolumn{1}{|c|}{ Category } & Frequency & Percent \\
\hline \multirow{2}{*}{$\begin{array}{l}\text { For what Purpose } \\
\text { did you borrow the }\end{array}$} & House hold Consumption & 10 & 4.0 \\
\cline { 2 - 4 } loan? & Purchasing Agricultural Input & 72 & 29.0 \\
\cline { 2 - 4 } & Undertaking Micro business & 50 & 20.2 \\
\cline { 2 - 4 } & Micro Industrial Activity & 11 & 4.4 \\
\cline { 2 - 4 } & Procurement of Fixed Assets & 105 & 42.3 \\
\cline { 2 - 4 } & Total & $\mathbf{2 4 8}$ & $\mathbf{1 0 0 . 0}$ \\
\hline
\end{tabular}

Source: Own Field Survey, 2017. 
At the above table most of the money is employed on fixed asset building as responded by $105(42.3 \%)$ members, whereas for undertaking productive activities only $72(29 \%)$ borrowed. The remaining samples response show that 10(4\%) for household consumption, 50(20.2\%) for undertaking micro business activities, and 11(4.4\%) micro industrial activities.

\subsubsection{Financial Flow of Rural Micro-Financing through SACCO's Effort}

The financial flow in this study encompasses the amount of loan disbursed to and saving mobilization of SACCOs from the members. According to the information gathered from the respondents and accounting document of SACCOs, the amount of loan disbursed to the members in three zones is summarized as:

Table 13. The amount of loan disbursed during last five years

\begin{tabular}{|l|c|c|c|c|c|c|c|}
\hline Zone & No. of & \multicolumn{7}{|c|}{ Loan Disbursed } \\
\cline { 3 - 8 } & Borrowers & $\mathbf{2 0 1 1}$ & $\mathbf{2 0 1 2}$ & $\mathbf{2 0 1 3}$ & $\mathbf{2 0 1 4}$ & $\mathbf{2 0 1 5}$ & Total \\
\hline Bench Maji & 104 & 75,000 & 350,000 & 325,270 & $1,125,250$ & 410,900 & $\mathbf{2 , 2 8 6 , 4 2 0}$ \\
\hline Keffa & 98 & 100,000 & 95,000 & 450,000 & 520,000 & 545,000 & $\mathbf{1 , 7 1 0 , 0 0 0}$ \\
\hline Sheka & 46 & 0 & 50,000 & 25,500 & 65,000 & 24,000 & $\mathbf{1 6 4 , 5 0 0}$ \\
\hline Total & $\mathbf{2 4 8}$ & $\mathbf{1 7 5 , 0 0 0}$ & $\mathbf{4 9 5 , 0 0 0}$ & $\mathbf{8 0 0 , 7 7 0}$ & $\mathbf{1 , 7 1 0 , 2 5 0}$ & $\mathbf{9 7 9 , 9 0 0}$ & $\mathbf{4 , 1 6 0 , 9 2 0}$ \\
\hline
\end{tabular}

Source: Own Field Survey, 2017.

The financial flow in this study encompasses the amount of loan disbursed to and saving mobilization of SACCOs from the members. According to the information gathered from the respondents and accounting document of SACCOs, the amount of loan disbursed to the members in three zones is summarized. As displayed in the above table the members borrowed 4,160,920 birr for the last five years in three zones. On average the loan disbursed in three zones is 16,778 birr. The researcher used three indicators like delivery, adequacy, and processing services of saving and credit activities to evaluate members' satisfaction. The crucial issue for the business man is to know the time value of money to be profitable or not in his business.

Table 14. Satisfaction on saving and credit service

\begin{tabular}{|l|c|c|c|c|c|c|}
\hline \multirow{2}{*}{ Category } & \multicolumn{2}{|c|}{ On Time Delivery } & \multicolumn{2}{c|}{ Loan Adequacy } & \multicolumn{2}{c|}{ Loan Process } \\
\cline { 2 - 7 } & Frequency & Percent & Frequency & Percent & Frequency & Percent \\
\hline Highly Agree & 106 & 33.1 & 82 & 25.6 & 94 & 29.4 \\
\hline Agree & 187 & 58.4 & 192 & 60 & 197 & 61.6 \\
\hline Don't Know & 14 & 4.4 & 15 & 4.7 & 8 & 2.5 \\
\hline Disagree & 8 & 2.5 & 26 & 8.1 & 14 & 4.4 \\
\hline Highly disagree & 5 & 1.6 & 5 & 1.6 & 7 & 2.2 \\
\hline \multicolumn{1}{|c|}{ Total } & $\mathbf{3 2 0}$ & $\mathbf{1 0 0}$ & $\mathbf{3 2 0}$ & $\mathbf{1 0 0}$ & $\mathbf{3 2 0}$ & $\mathbf{1 0 0 . 1}$ \\
\hline
\end{tabular}

Source: Own Field Survey, 2017. 


\section{Macrothink}

World Journal of Business and Management

ISSN 2377-4622

2018, Vol. 4, No. 2

The price always changes and causes market inflation, therefore money value also changes. As shown in table above on time delivery of credit service to members is good that is $106(33.1 \%)$ highly agreed and $187(58.4 \%)$ are agreed. Adequacy of credit service given to members implies that 82(25.6\%) highly agrees, 192 (60\%) agrees, 15(4.7\%) don't know, $26(8.1 \%)$ disagree, and 5(1.6\%) are highly disagree. Regarding the members' satisfaction on loan processing service $94(29.4 \%)$ highly agreed and 197(61.6\%) agreed out of 320 respondents.

Table 15. Members opinion on SACCOs contribution

Do you agree that SACCOs contributed in solving the financial problem of members?

\begin{tabular}{|c|c|c|}
\hline Response & Frequency & Percent \\
\hline Yes & 271 & 84.7 \\
\hline No & 49 & 15.3 \\
\hline Total & $\mathbf{3 2 0}$ & $\mathbf{1 0 0}$ \\
\hline
\end{tabular}

Source: Own Survey, 2017.

The study focused here is on two contributions of SACCO's especially solving financial problems of members and income improvement of the members. Regarding the opinion on SACCOs' contribution in solving the financial problem of members the data above show that $271(84.7 \%)$ responded that the SACCO has contributed in solving their financial problem while the remaining 49(15.3\%) replied didn't contributed.

Table 16. Income improvement

\begin{tabular}{|l|l|c|c|}
\hline \multicolumn{1}{|c|}{ Description } & Category & Frequency & Percent \\
\hline \multirow{3}{*}{$\begin{array}{l}\text { Income improvement due } \\
\text { to membership }\end{array}$} & Decreased & 17 & 5.3 \\
\cline { 2 - 4 } & No change & 46 & 14.4 \\
\cline { 2 - 4 } & Increased & 257 & 80.3 \\
\cline { 2 - 4 } & Total & $\mathbf{3 2 0}$ & $\mathbf{1 0 0}$ \\
\hline \multirow{3}{*}{$\begin{array}{l}\text { Reason for Improvement of } \\
\text { Income }\end{array}$} & Increasing Business Volume & 131 & 51.0 \\
\cline { 2 - 4 } & Starting New Business & 69 & 26.8 \\
\cline { 2 - 4 } & Starting Micro Business & 13 & 5.1 \\
\cline { 2 - 4 } & Other & 44 & 17.1 \\
\cline { 2 - 4 } & Total & $\mathbf{2 5 7}$ & $\mathbf{1 0 0}$ \\
\hline
\end{tabular}

Source: Own Survey, 2017.

As shown in table 14 above $80.3 \%$ of the respondents replied as their yearly income after they have been participated in the SACCO is improved, $14.4 \%$ of them replied no change and the remaining 5.3\% replied that there is decrease in their income. The reason for increasing their income is due to increased business volume as $131(51 \%)$ respondents, $69(26.8 \%)$ due to starting new business, $13(5.1 \%)$ due to starting micro business, and 44(17.1\%) due to other activities. 


\subsubsection{Challenges and Opportunities for Rural SACCOs}

In order to identify the challenges and opportunities to rural saving and credit cooperatives for performing their service are studied through distributing questionnaires and interviewing officers.

Table 17. Challenges of SACCO in loan administration

\begin{tabular}{|l|c|c|c|}
\hline \multicolumn{1}{|c|}{ The Main Challenges in SACCOs Loan Administration? } & Frequency & Percent & Rank \\
\hline High Interest Rate & 58 & 18.1 & $3^{\text {rd }}$ \\
\hline Short Period for Loan Collection & 137 & 42.8 & $1^{\text {st }}$ \\
\hline Non Proper Application of Credit Manual & 47 & 14.7 & $4^{\text {th }}$ \\
\hline Inadequate Amount of Loan & 78 & 24.4 & $2^{\text {nd }}$ \\
\hline \multicolumn{1}{|c|}{ Total } & $\mathbf{3 2 0}$ & $\mathbf{1 0 0 . 0}$ & \\
\hline
\end{tabular}

Source: Own Survey, 2017.

As displayed above, 58(18.1\%) replied high interest rate, 137(42.8\%) said short repayment period, 47(14.7\%) replied non proper application of credit manual, and 78(24.4\%) responded that there is inadequacy on amount of loan supply.

Table 18. Members' opinion on interest rate of loan

\begin{tabular}{|l|c|c|c|}
\hline \multicolumn{1}{|c|}{ Description } & Response & Frequency & Percent \\
\hline \multirow{3}{*}{$\begin{array}{l}\text { Member's Opinion Regarding Interest } \\
\text { Rate on Loan }\end{array}$} & High & 59 & 18.4 \\
\cline { 2 - 4 } & Medium & 215 & 67.2 \\
\cline { 2 - 4 } & Low & 46 & 14.4 \\
\cline { 2 - 4 } & Total & $\mathbf{3 2 0}$ & $\mathbf{1 0 0}$ \\
\hline
\end{tabular}

Source: Own Survey, 2017.

To know the perception of members on loan interest rate in SACCCO's the questionnaire was distributed and come with the above responses. Out of 320 respondents regarding the interest rate $59(18.4 \%)$ replied as it is high, $215(67.2 \%)$ said medium, and the remaining 46(14.4\%) said low.

\subsection{Discussion of Findings}

Collecting the socio-demographic characteristics in this study was required to evaluate the role of SACCO's in improving rural microfinance mobilization that starts from the definition and principle of cooperatives. Though the total rural populations of the study area are approximately 1,552,057 based on Central Statistics Agency census report (2007 E.C), the SACCO members are only 15,371(0.99\%).

Since our study focused on rural SACCO the literacy composition is good to manage the 


\section{$\triangle$ Macrothink}

Cooperative society. But when we look at individual level due to their business special characteristics to the financial business it is preferable to train the members as the highest number is below $12^{\text {th }}$ grade. The population of one community comes from the increase or decrease of family size and the family size is dependent up on the marital status of that community in normal condition. In ordinary thinking if the family size increases the householder or house maid needs additional income to serve that family.

When speaking about the improvement of rural micro finance through the role of saving and credit cooperatives, this study focused on ideological preparedness of community on saving of resources, the tool to improve members saving culture, the members actual deposit in their SACCO, and credit facilities performed by SACCO's.

According to the finding SACCOs have great contribution in changing the saving culture of the members and increasing the financial saving which improves the rural microfinance mobilization. The training as a tool has contributed on changing the saving culture of rural members on efficient and effective utilization of resources; however frequency and coverage of training is limited. Even though, in their bylaws every member must save fixed amount of money regularly in the form of deposit in prescribed time, the receipt journal of the societies shows that there is irregularity of saving the money by some members.

The concept of loan facilitation in this paper includes enacting loan focused rule and regulation of each society, availing enough finance for loan distribution, determining reasonable interest rate on loan, setting criteria for loan disbursement and repayment period. During the field survey the researcher observed the legal documents of the societies, such as bylaws, credit directives, Credit committee minutes, different formats to be fulfilled, and payment systems. All sample cooperative societies have bylaws already prepared by the government as model and based on this the societies have prepared their own by law, enacted credit directives, established minutes, but most of them don't apply it fully.

The finding displayed that there is better loan distribution performance of Cooperatives; however there are issues to be managed critically. In other way only $5 \%$ of the members have the membership duration below 6 month who is not eligible to get loan according to the bylaw, but the rest $95 \%$ were being members in cooperatives for more than 6 month. As there are only $16(5 \%)$ members cannot borrow money according to their bylaw, but $22.5 \%$ were not borrowed at all who were eligible to borrow. The reason identified for limited performance during field survey were members weakness to repay their loan on predetermined period, shortage of evaluation on members business plan by SACCO management, managers weakness in collection of loan receivable, shortage of capital to lend loan.

\subsubsection{Financial Flow of Rural Micro-Finance}

1). Loan Disbursement: Saving and Credit Cooperatives in study area during the last five years disbursed to the members 4,160,920 birr. This is only the birr amount that sample respondents borrowed from their cooperatives. In study areas there are 15,361 members from three unions' member primary SACCO's. 
2). Saving Mobilization of Cooperatives: regarding the saving mobilization of saving and credit cooperatives in study area birr 14,789,427 being deposited for the fast five years from the members. As identified there is good performance of SACCOs on time delivery of loan service for their members. Based on the individuals' business plan the loan they will get should at list adequate to operate their business. Through this stand point the researcher surveyed and the result showed that the loan provision is adequate. Though it seems adequate, some members commented that in current market situation the money they borrow is not enough to purchase what they want. In most cooperative societies the loan processing service is weak as identified.

Absence of income generating source is the main driving force of poverty in developing country to lead their life. There is an improvement of income due to the membership in SACCO due to increased existing business volume, starting new business, and undertaking other activities. Even though there is income improvement using the loan from their cooperatives; some of members are not successful due to misappropriate use of money, market failure, and limitation of business skill. In most cases the rural community now a days are well aware on building fixed assets especially house construction, grain meal construction etc. The information from the study indicated most members use borrowed money to acquire fixed asset especially acquiring furniture, electronics, and construction of houses.

Based on the study the challenges identified are shortage of finance for loan distribution, members weakness in regular saving, management weakness in collection of loan receivables, weak awareness creation and information transmission activities of both SACCO's and promotion office to all rural community for being member in the society, and limited support of government to SACCO's lower administrative level. The opportunities for cooperatives to perform their operation are establishment of promotion office from Federal up to kebele level, provision of different cooperative organization and promotion laws, working of some financial supporting and capacity building NGOs around SACCOs, opening and expanding cooperative departments in universities throughout the country, academic researches' focusing on cooperative development.

\section{Conclusion and Recommendation}

\subsection{Conclusion}

The cooperatives in our country are expected as the proximate economic and social welfare enhancing instruments. Poverty reduction program can be effective if and only if cooperatives work towards increasing the productivity of agriculture besides to other sectors. Based on this stand point SACCOs have been organized in enhancing the saving culture of the rural community and supplying finance through loan disbursement to the members. In developing countries including Ethiopia, majority of the community are living with food insufficiency as their income generating capacity is weak due to shortage of finance to undertake additional business for fulfilling food shortage and income generation gap. Therefore, strengthening the purchasing capacity of the rural community of Ethiopia is the crucial issue for Government of Ethiopia. Considering the upper mentioned and other development agendas the government of Ethiopia has given attention in its policy how to solve the rural communities' financial 
shortage. Practically there are many government sponsored and private initiated micro financial institutions including saving and credit cooperatives established and started saving and credit activities throughout the country.

This research was focused on four areas to identify the role of SACCOs such as contribution of SACCOs in changing the saving culture of the members, loan provision performance of the SACCOs, financial flow in rural micro-financing based on saving and credit cooperatives effort, and the challenges faced the cooperatives on undertaking this business. Some encouraging performances have been observed in this study regarding the role of saving and credit cooperatives. In Cooperative Principles the only beneficiaries of the cooperatives are the members. Based on this principle in the study area the number of members of saving and credit cooperatives are only 15,371 (0.99\%) out of 1,552,057 rural people in three Zones. Even though out of the members the majority part are users of loan from the society and all of the members are compulsory savers, without covering millions of rural community its role is insignificant. There is an improvement in saving culture but still it requires strong work in awareness creation through training and education because some members deposits their compulsory saving irregularly and most of savers deposits only for the sake of loan.

There are issues to be managed critically according to the cooperative bylaw as such all members above 6 month must get loan when applied. The reason identified for drawback in performance during field survey was legal case which prevents members not to be guaranteed for loan who are below six month in member ship. In the study area the only micro finance institution serving the community is Omo Micro Finance Institution (OMFI). When compared to saving and Credit Cooperatives its financial source is fully sponsored by government, hence they have greater financial power than SACCOs. Even though they are government sponsored, still didn't cover the interest of the rural community at all.

In performing financial activity they must satisfy the need of members. Though the result shows it is satisfactory; in reality in current market the money they borrow is not enough to purchase what they need. So it needs revision on the level of loan amount to be borrowed. The loan processing service of saving and credit cooperative societies is the important management activity which creates satisfaction or dissatisfaction on the members. The loan process starts from establishing clear loan rule, appointing appropriate loan committee, planning the amount of money for loan provision in annual budget, availing the budgeted money on time, preparing account receivables account, assigning the responsible body to handle receivables, preparing different documents for loan disbarment activities like loan committee minute, approval sheets, members' business plan. During field survey most of SACCOs have fulfilled and follow these processes but some of them by passes most parts especially the evaluation of business plan is very weak. There is also a drawback on regularity of committee meeting and planed follow up of loan collection.

\subsection{Recommendation}

In the previous part of the chapter, it is concluded in such a way that one can see the status of rural saving and credit cooperatives in playing role to improve micro financial mobilization in rural area. Having these conclusions in mind, the following recommendations are 
forwarded:

1) To increase capital accumulation and fulfill the members' financial need they have to work hard in order to increase the number of members so that they can sale huge number of share. Based on the increase of number of members both capital of cooperatives and deposits of members will increase.

2) The cooperative management must maintain subsidiary ledger for receivables collection and follow up,

3) They have to give continuous training and awareness for the members to deposit regularly and arrange incentive for active depositors'.

4) Government of Ethiopia at first must establish strong and active education, training, and information unit at Zone and Woreda level with regular training provision to members, mass mobilization on cooperative education to all rural community,

5) check the correct employment of legal provisions whether they are applicable with respect to Ethiopian context because both cooperative proclamations and the preceding bylaws are always dependent to ICA principle, and must avail well-structured capital injection and networking with other financial institutions to SACCOs.

6) Most of SACCOs are incapable financially to hire experts. Therefore it is better to support recruiting and training experts through government and NGOs.

7) With their special proximity to the community Cooperatives can give better financial service to the community mobilizing saving which is the interest of government to collect idle cash in to government treasury. Therefore, the government must give attention to collaborate SACCOs, Micro financial Institutions, private and public banks, and other Cooperatives without abiding the cooperative rules.

Generally this research come with recommending highlights studying in narrow areas, therefore broad and exclusive study must be done national wise by encompassing different stakeholders such as academicians, cooperative agency experts, economists and other interested bodies.

\section{Acknowledgements}

I have great appreciation to family and friends who were on besides me until to end up the paper work. My former Department colleagues, Mr. Matthewos Haile and Bewket Belay are in my heart for ever since they were with me until to leave the university and encouraged me even after leaving the university. Also I have great respect to my College and Research directorate for financial and moral support. For unforgettable support during data collection period, I have great appreciation to Bench Maji, Kaffa, and Sheka (Yeki woreda) Zone Cooperative promotion office, unions, Primary SACCO Management bodies and Maji Woreda Administrative office. God did all through my research work, therefore thank you for your endless support. 


\section{References}

Alila, P. O., \& Obado, P. O. (1990). Cooperative credit: The Kenyan saving and Credit Cooperatives in a historical and development perspective. Institute for development studies, University of Nairobi, working paper no.

Aregawi, G. T. (2014). Financial Performance of Rural Saving and Credit Cooperatives in Tigray, Ethiopia. Research Journal of Finance and Accounting, 5(17).

Bwana, K. M., \& Mwakujonga, J. (2013). Issues in SACCOS Development in Kenya and Tanzania: The Historical and Development Perspectives. Developing Country Studies, 3(5), 114-122.

Dessalew, A. (2014). The Socio-Economic Role of Saving and Credit Cooperatives in Promoting Gender Equality: The Case of Estie Woreda, Ethiopia. European Journal of Business and Management, 6(1), 1-7.

Douglas, A. A. (2012). Microcredit, Income Assistance, and Households' Time Allocation to Self-employment. University of Saskatchewan, Saskatoon.

Eoin, W. T. (2005). Finance, Microfinance, Resource for NGOs Reviews. MicroFinance_literature_review.pdf.

Federal Cooperative Agency. (2016). National Saving and credit Cooperative societies Mobilization Manual, Amharic version. Addis Ababa, Ethiopia.

Federal Negarit Gazeta of the Federal Democratic Republic of Ethiopia. (1998). Cooperative Societies Proclamation 147/1998, 5th Year No. 27. ADDIS ABABA, Ethiopia.

Federal Negarit Gazeta. (2016). Cooperative Societies Proclamation No. 985/2016, No.7 $23^{\text {rd }}$, p. 9458. Addis Ababa, Ethiopia.

Getachew, M. T. (2006). Working paper: Sustainable SACCO development.

Henama, U. S. (2012). Trade union savings and credit operatives: The case of national education, health and allied workers, savings and credit co-operative in South Africa, International Journal of Cooperative Studies, 1(1).

Jeremiah, M. K., \& Bichanga, O. (2014). Financial Factors Influencing Performance of Savings and Credit Co-Operative Organization in Kenya. International Journal of Academic Research in Accounting, Finance and Management Sciences, 4(2), 291-302.

Kifle, T. S. (2012). The Impact of Savings and Credit Cooperatives in Ofla Wereda, Tigray Region of Ethiopia.

Kimberly, A. Z., \& Robert, C. (1980). Cooperatives: Principles and Practices in the $21^{\text {st }}$ century (4th ed.). University of Wisconsin Extension-Madson, Publication A1457.

Microfinanceinafrica.pdf (Accessed, 2018, P. 1). Combining the Best Practices of Traditional and Modern Microfinance Approaches towards Poverty Eradication. 
Muluneh, A. (2012). Financial Inclusion Buttress incomes, assets, reduce vulnerability to shocks, Birritu2012 No 113

Mwakajumilo, S. L. I. (2011). The Role of Informal Microfinance Institutions in Saving Mobilization, Investment and Poverty Reduction: A Case of Savings and Credit Cooperative Societies in Tanzania from 1961-2008.

Nigusie, D. (2015). Determinants of Savings and Credit Cooperatives Societies (SACCOs) outreach in Addis Ababa. A thesis Submitted to the Department of Accounting and Finance, College of Business and Economics, Addis Ababa University.

Ofei, K. A. (2001). Retooling Credit Unions: the Case of Credit Union, Association of Ghana. International labor organization IFLIP Research Paper 01-3.

Okoye, G. (2009). The Role of Financial Services Cooperatives FSCs/SACCOS in Savings Mobilization and Economic Development. Paper presented to the first International Conference held at the ICC-DURBAN 23rd - 26th February.

Olando, C. O. et.al. (2012). Financial Practice as the Determinant of Growth of SACCOs' Wealth. International Journal of Business and Social Science, 3(24), 204-219.

Olga A. A. et al. (2017). Factors Affecting the Financial Performance of Savings and Credit Co-Operative Society in Kenya: A Case of Mwalimu Savings and Credit Co-Operative Society. Imperial Journal of Interdisciplinary Research (IJIR), 3(4).

Pacific Financial Inclusion Program. (2009). Definition \& Evolution of Microfinance, Fiji National Microfinance Workshop: Medium Term Strategy for Financial Inclusion in Fiji, 4-5 November, 2009 Novotel, Lami

Srinivasan, R., \& Sriram, M. S. (2003). Microfinance: An Introduction. IIMB Management Review, June 2003

The World Bank. (2013). The new Microfinance Handbook: A financial Market System Perspective. 2013 International Bank for Reconstruction and Development / The World Bank 1818 H Street NW, Washington DC.

Thierry, T. (2018). Microfinance in Africa Banking for the Smallest Businesses: IFC, world Bank Group. (ifc+Africa+microfinance+brochure.pdf, accessed, 2018).

Wolday, A. (2004). The Development Microfinance Industry in Ethiopia: Current Status and the Prospect for Growth.

\section{Glossary}

BOD Board of Directors

CC Control Committee

CSA Central Statistical Agency of Ethiopia 


\section{Macrothink

FCA Federal Cooperative Agency

ICA International Cooperative Alliance

OMF Omo Micro Finance

OMFI Omo Micro Finance Institution

PFIP Pacific Financial Inclusion Program

RUSACCO Rural Saving and Credit Cooperatives

SACCO Saving and Credit Cooperatives

SNNPRS South Nations, Nationalities, and Peoples Regional state

\section{Copyright Disclaimer}

Copyright for this article is retained by the author(s), with first publication rights granted to the journal.

This is an open-access article distributed under the terms and conditions of the Creative Commons Attribution license (http://creativecommons.org/licenses/by/3.0/). 